



\title{
Boletín del Museo Chileno de Arte Precolombino
}

\author{
VOLUMEN 18 | NÚMERO 1
}

Santiago, 2013

ILUSTRE MUNICIPALIDAD DE SANTIAGO

FUNDACION FAMILIA LARRAIN ECHENIQUE

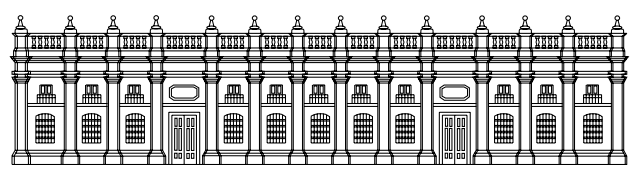





\section{Contenido}

\section{7-8 Presentación}

Foreword

9-23 Identificación de una técnica de elaboración de botellas Moche de asa estribo en El Castillo de Santa, costa norte de Perú

Identifying techniques used to construct Moche stirrup spout bottles from El Castillo de Santa, northern coast of Peru

Jorge Gamboa Velásquez

25-48 Paisaje monumental y complejidad social en los pescadores arcaicos de la costa de Arica: Análisis de materialidad y arte pictórico en la cueva La Capilla

Monumental landscape and social complexity among the archaic fishermen of the Arica coast: An analysis of the materiality and pictorial art at La Capilla cave

Iván Muñoz Ovalle

49-66 Las pinturas costeras de Chomache y su contexto económico-social (Región de Tarapacá, norte de Chile)

Coastal Chomache paintings and its economic and social context (Tarapacá Region, northern Chile)

Gloria Cabello, Francisco Gallardo \& Carolina Odone

67-83 Hematita vs. arcillas: Su potencial como pigmentos rojos y su uso en tres sitios de la Puna jujeña (Argentina)

Hematite vs. clays: Their potential as red pigments and their use in three sites at the Puna of Jujuy (Argentina)

Patricia Solá, Hugo D. Yacobaccio, Mariana Rosenbusch, María Susana Alonso, Marta

S. Maier, Cristina Vázquez \& María Paz Catá

85-106 La metalurgia de los valles orientales del norte de Salta, Argentina

Metallurgy of the eastern valleys of North Salta, Argentina

Beatriz Ventura \& Ana Clara Scambato

107-124 La plaza y el ushnu de Hualfín Inka: Interpretaciones acerca de su función en la arquitectura pública del período inkaico

The plaza and the ushnu of Hualfin Inka: Interpreting their function in the public architecture of the Inka period

Julieta Lynch

125-137 La elección de rocas de colores por los pobladores tempranos de la región pampeana (Buenos Aires, Argentina): Nuevas consideraciones desde las canteras

The choice of colored toolstone by early settlers of the Pampas (Buenos Aires, Argentina): New viewpoints from the quarries

Mariano Colombo \& Nora Flegenheimer 



\section{Presentación}

El número 1 del Volumen 18 de la revista trae un misceláneo si bien no menos interesante elenco de trabajos de arqueología, que abarca desde el litoral septentrional de Perú hasta las pampas argentinas.

Abre la presente entrega el artículo de Jorge Gamboa sobre la cerámica de la Fase Moche III del sitio El Castillo de Santa, un asentamiento de la costa norte de Perú que data de entre 300 y 600 DC. El autor identifica una modalidad de manufactura de botellas de asa estribo hasta ahora desconocida, mostrando la existencia de diferentes métodos y cadenas operativas en su fabricación, aportando así al conocimiento de la diversidad de la producción alfarera en Moche, tanto en un plano regional como cronológico.

El siguiente artículo, escrito por Iván Muñoz, se concentra en La Capilla, una cueva localizada en el borde costero del extremo norte de Chile, a pocos kilómetros al sur de la ciudad de Arica. Este singular sitio fue ocupado por pescadores del Período Arcaico Tardío, hace entre 3800 y 2800 años, contiene bellas pictografías y ha entregado un interesante conjunto de restos materiales. Estas evidencias son analizadas por Muñoz para conocer la interacción social que tuvo lugar dentro de la cueva y las funciones que desempeñó el sitio, en el marco de conceptos como paisaje monumental y complejidad social.

Gloria Cabello, Francisco Gallardo y Carolina Odone analizan la iconografía de las pictografías del sitio costero de Chomache 58; la correspondencia de estas imágenes con aquellas presentes en sitios de arte rupestre, cerámica, tejidos y cestos del interior; el hallazgo en el sitio de productos y materias primas de desierto adentro; las rutas de tráfico y su equipamiento vial, y algunos relatos del período histórico. Lo hacen para perfilar las articulaciones entre grupos pescadores y comunidades agroganaderas de la Región de Tarapacá durante la primera mitad del segundo milenio de la Era. Según los autores, estas relaciones ponen de manifiesto una complementariedad entre ambas poblaciones, que es tanto ecológica como social y cultural.

En el cuarto artículo, Patricia Solá y coautores analizan los pigmentos de color rojo de las pinturas rupestres de Hornillos 2, Cueva Quispe y Tres Pozos, todos ubicados en la puna de Jujuy, Argentina. Los sitios datan, respectivamente, del Pleistoceno final / Holoceno temprano a medio, Período Formativo a Tardío y Período Formativo. Los niveles estratigráficos de dos de 
estos sitios proveyeron pigmentos rojizos constituidos por hematita y arcillas rojas, aunque estas últimas parecen no haber sido empleadas en las pictografías. Sugieren que el uso de uno u otro tipo de pigmento estuvo vinculado con sus propiedades intrínsecas y que esta elección apuntaba a fines diferentes.

El artículo de Beatriz Ventura y Ana Clara Scambato es un trabajo de síntesis sobre la metalurgia de los valles orientales del norte de Salta, Argentina, en tiempos de la ocupación inka. Para ello, las autoras examinan un amplio número de fuentes, incluyendo información arqueológica publicada, análisis de colecciones en museos, datos geológicos y documentos etnohistóricos.

El foco de interés del artículo de Julieta Lynch es la dinámica de la expansión inkaica y su impacto sobre las poblaciones del centro de la Provincia de Catamarca, Argentina. Mediante el estudio de la plaza y el ushnu de Hualfín, la autora examina las estrategias de control cusqueño, concluyendo que la política expansiva de los inkas hizo uso de la coerción, pero también de diversas modalidades de negociación e inclusión de las comunidades locales en la estructura del Estado.

En el artículo que cierra este número, Mariano Colombo y Nora Flegenheimer reflexionan sobre la posible valoración de los colores que habrían tenido los cazadores y recolectores de la región pampeana de Argentina de hace unos 11.000 años, tomando como referentes las materias primas líticas elegidas para manufacturar artefactos de piedra. Los datos provienen de canteras arqueológicas que proveyeron rocas de diferentes colores. Los autores confirman la relevancia del color y otras propiedades de las rocas y los minerales entre los cazadores y recolectores, sugiriendo que en la comunicación visual de estos tempranos pampeanos estas cualidades fueron valoradas desde un punto de vista estético. 